\title{
Effect of the Enhanced Recovery After Surgery protocol After Colorectal Cancer Surgery
}

\author{
Dae Ro Lim \\ Division of Colon and Rectal Surgery, Department of Surgery, Soonchunhyang University Bucheon Hospital, Soonchunhyang University \\ College of Medicine, Bucheon, Korea
}

\section{See Articles on Page 264-272}

The enhanced recovery after surgery (ERAS) program is first introduced by Bardram et al. [1] in the mid-1990s, which aims to reduce surgical stress, accelerate the length of postoperative functional recovery, and reduce postoperative morbidity [2]. Since the first guidelines for colorectal surgery were published in 2005, the ERAS Society care pathways include evidence-based items designed to reduces perioperative stress, maintain postoperative physiological function, and accelerate postoperative recovery after colorectal surgery $[2,3]$. The ERAS protocol usually contains 3 components; preoperative, intraoperative, and postoperative component. Each subdivided element is diverse, but if it is classified as a large item, the preoperative component includes preoperative counseling, anesthesiology consultation, and carbohydrate loading prior to surgery. The intraoperative component includes perioperative normothermia in the operation room or on arrival to the postoperative recovery unit, multimodal analgesia, prophylaxis of postoperative nausea and vomiting, and postoperative monitoring and fluid therapy. The postoperative component includes adequate postoperative fluid therapy, prevention of postoperative ileus, urinary drainage, glycaemic control, and nutritional care. This ERAS protocol is effective in reducing postoperative complications, improve recovery, and shorten the length of stay in patients after colorectal surgery [4-6]. It is reported that this ERAS protocol is effective not only in elective open colorectal surgery

Correspondence to: Dae Ro Lim, M.D.

Division of Colon and Rectal Surgery, Department of Surgery,

Soonchunhyang University Bucheon Hospital, 170 Jomaru-ro, Wonmi-gu,

Bucheon 14584, Korea

Tel: +82-32-621-6267, Fax: +82-32-621-6950

E-mail: limdaero@schmc.ac.kr

ORCID: https://orcid.org/0000-0002-3076-1391

(C) 2020 The Korean Society of Coloproctology

This is an open-access article distributed under the terms of the Creative Commons Attribution NonCommercial License (https://creativecommons.org/licenses/by-nc/4.0) which permits unrestricted noncommercial use, distribution, and reproduction in any medium, provided the original work is properly cited.
[7], but also in laparoscopic surgery [8], emergency surgery [9], and elderly patient surgery [10]. The ERAS protocol can be considered to reduce postoperative complication by reducing the systemic inflammatory response after colorectal surgery, but few studies have proven the relationship between the ERAS protocol and inflammatory markers (C-reactive protein, interleukin-6, neutrophil-lymphocyte ratio, and so on) [11]. A recent study reported that ERAS protocol can reduce the increase in postoperative neutrophil-lymphocyte ratio in patients with colorectal cancer [12]. However, the study on this is still lacking. Another important point in the ERAS protocol is compliance. The higher the compliance of the patients, the higher benefit will be, and the lower it is, the lower the benefit after surgery $[6,13]$. There are various factors affecting ERAS compliance such as age. Therefore, ERAS needs to be improved in the future according to various factors so as to increase compliance through various studies.

A recent published study report that it demonstrated the relationship between the ERAS protocol and inflammatory marker after colorectal cancer surgery. In this well designed study reported that analysis of effect of the ERAS protocol and compliance on postoperative inflammation and short term postoperative surgical outcomes after colorectal surgery [14].

\section{CONFLICT OF INTEREST}

No potential conflict of interest relevant to this article was reported.

\section{REFERENCES}

1. Bardram L, Funch-Jensen P, Jensen P, Crawford ME, Kehlet H. Recovery after laparoscopic colonic surgery with epidural analgesia, and early oral nutrition and mobilisation. Lancet 1995;345: 763-4.

2. Fearon KC, Ljungqvist O, Von Meyenfeldt M, Revhaug A, Dejong $\mathrm{CH}$, Lassen $\mathrm{K}$, et al. Enhanced recovery after surgery: a consensus review of clinical care for patients undergoing colonic resection. Clin Nutr 2005;24:466-77. 
3. Gustafsson UO, Scott MJ, Hubner M, Nygren J, Demartines N, Francis N, et al. Guidelines for perioperative care in elective colorectal surgery: Enhanced Recovery After Surgery (ERAS ${ }^{\circledR}$ ) Society Recommendations: 2018. World J Surg 2019;43:659-95.

4. Gustafsson UO, Hausel J, Thorell A, Ljungqvist O, Soop M, Nygren J. Adherence to the enhanced recovery after surgery protocol and outcomes after colorectal cancer surgery. Arch Surg 2011;146:571-7.

5. Khoo CK, Vickery CJ, Forsyth N, Vinall NS, Eyre-Brook IA. A prospective randomized controlled trial of multimodal perioperative management protocol in patients undergoing elective colorectal resection for cancer. Ann Surg 2007;245:867-72.

6. Ripollés-Melchor J, Ramírez-Rodríguez JM, Casans-Francés R, Aldecoa C, Abad-Motos A, Logroño-Egea M, et al. Association between use of enhanced recovery after surgery protocol and postoperative complications in colorectal surgery: the Postoperative Outcomes Within Enhanced Recovery After Surgery Protocol (POWER) Study. JAMA Surg 2019;154:725-36.

7. Varadhan KK, Neal KR, Dejong CH, Fearon KC, Ljungqvist O, Lobo DN. The enhanced recovery after surgery (ERAS) pathway for patients undergoing major elective open colorectal surgery: a meta-analysis of randomized controlled trials. Clin Nutr 2010;29: 434-40.

8. Pedrazzani C, Conti C, Mantovani G, Fernandes E, Turri G, Laz- zarini E, et al. Laparoscopic colorectal surgery and Enhanced Recovery After Surgery (ERAS) program: experience with 200 cases from a single Italian center. Medicine (Baltimore) 2018;97:e12137.

9. Lohsiriwat V, Jitmungngan R. Enhanced recovery after surgery in emergency colorectal surgery: review of literature and current practices. World J Gastrointest Surg 2019;11:41-52.

10. Bagnall NM, Malietzis G, Kennedy RH, Athanasiou T, Faiz O, Darzi A. A systematic review of enhanced recovery care after colorectal surgery in elderly patients. Colorectal Dis 2014;16:94756.

11. Watt DG, McSorley ST, Horgan PG, McMillan DC. Enhanced recovery after surgery: which components, if any, impact on the systemic inflammatory response following colorectal surgery?: a systematic review. Medicine (Baltimore) 2015;94:e1286.

12. Liu X, Wang Y, Fu Z. Impact of enhanced recovery after surgery on postoperative neutrophil-lymphocyte ratio in patients with colorectal cancer. J Int Med Res 2020;48:300060520925941.

13. Cavallaro P, Bordeianou L. Implementation of an ERAS pathway in colorectal surgery. Clin Colon Rectal Surg 2019;32:102-8.

14. Jalloun HE, Lee IK, Kim MK, Sung NY, Al Turkistani SA, Park $\mathrm{SM}$, et al. Influence of the enhanced recovery after surgery protocol on postoperative inflammation and short-term postoperative surgical outcomes after colorectal cancer surgery. Ann Coloproctol 2020;36:264-72. 